\title{
The Relationship between Family Lifestyle and Physical Activity of Children from 4 to 6 Years
}

\author{
Karina Ferreira Melo ${ }^{1}$, Sane Bandeira de Barros ${ }^{1}$, Taina Portugal Santos ${ }^{1}$, Ademir De Marco ${ }^{2}$, \\ Vinicius Barroso Hirota ${ }^{3}$, Caroline Belli Amorim de $\mathrm{Sa}^{1}$ \\ ${ }^{I}$ Department of Physical Education - Nossa Cidade-Estácio College - São Paulo, Brazil. \\ ${ }^{2}$ Department of Physical Education - UNICAMP - Campinas, Brazil. \\ ${ }^{3}$ Department of Physical Education - Methodist University of São Paulo, Sacramento St., 230, IOTA, sala 294. \\ Rudge Ramos, zip: 09640-000 - São Bernardo do Campo, SP-Brazil
}

*Corresponding Author: Vinicius Barroso Hirota, Department of Physical Education - Methodist University of São Paulo, Sacramento St., 230, IOTA, sala 294. Rudge Ramos, zip: 09640-000 - São Bernardo do Campo, SP-Brazil

\begin{abstract}
Today we are faced with the conflict of the number of tasks and the possibility of having an active life, however how much this can reflect in the future lifestyle of the children. in this way the objective of this work was to verify what physical activities are practiced by children, both inside and outside school, and whether the parents' lifestyle reflects this reality. counting on a descriptive research we applied a questionnaire structured in 24 parents; consisted of 24 children of both sexes, from 4 to 6 years of age (mean age $4.85 \pm 0.93$, coefficient of variation of $19.17 \%$, showing only the homogeneous sample in relation to age); of these, 13 boys evaluated and 07 girls. The results we could observe that the parents' lifestyle reflects directly on the children's life type, since the parents can direct the children, showing them and directing them to the practice of physical activities and still we verify that the boys work more than girls, by participating and leading a more active life.
\end{abstract}

Keywords: Family; Sedentary lifestyle; Children; Physical Activities.

\section{INTRODUCTION}

We have now observed that parents have spared their children from playing, in Brazil, in the streets and parks, as a result of the great urban violence, in contrast the children have spent their time in front of television, video games, cell phones and computers.

With this, society begins to be formed by a generation of children, adolescents and adults surrounded by technology and every day more afraid of going out on the streets, diminishing the interaction between children, and consequently with a healthy lifestyle. In addition, it should be emphasized the parents' lesser interaction with their children, due to the workaholic life, resulting in a shorter time of family life and leisure.

The family is the complex social organization, a part of society, where at the same time the primary relationships are lived and the identification processes are constructed. It is also a space where social roles of gender, class culture and the bases of power are reproduced. It is also the locus of politics, taught in the daily lives of people, in the discussions of children with parents, in decisions about the future, which at the same time has the world surrounding as a reference the desire and the conditions of possibility as limitations. For all this, it is the space of affection and also of conflict and contradictions (Minayo, 1999).

It is in the family that individuals relate and exchange experiences, since it is at the same time a space of cooperative conflict and a determinant space of well-being through the distribution of resources, often passing directly to reflect doubts, aspirations and personal issues. In the family, the children and other members find the space that guarantees their survival, development, well-being and full protection through affective and, above all, material contributions (Nascimento, 2006). In this way we 
must be attentive to the profile played in the family, and the consequences that this type of life can be developed with the children.

The physical activities of children were considerably reduced by contemporary society, concerned with safety, as well as with educational institutions, thereby reducing the time of motor and sport practices (Greco and Benda, 1998).

Rendering to Aerts et al. (2004) for the process of life transformation, it is fundamental to understand the determination of the social, political, cultural and physical environment on the health of individuals and collectivities; However, in order to enable this understanding, it is necessary to discuss how styles, habits and living and working conditions influence the ways of getting sick, dying and receiving health care.

According to Nahas (2006), Lifestyle, is the set of daily actions that reserves the attitudes and values of people. These conscious habits and actions are associated with the perception of the individual's quality of life. Lifestyle components can change over the years, but this only happens if the person consciously sees some value in some behavior that should include or exclude, in addition to perceiving himself as capable of making the desired changes.

An individual who has a lifestyle with a minimum of physical activity equivalent to an energy expenditure (work + leisure + activity + domestic + locomotion) of less than $500 \mathrm{kcal}$ per day is considered sedentary (Nahas, 2006).

According to Tornquist et al. (2013) schools should create opportunities for engaging in appropriate physical activities so that as children develop their motor skills.

Recent studies have shown that proportionally overweight and obese children were the ones that had the lowest level of physical activity, but there was no direct correlation between levels of physical activity and body mass index (Vale et al., 2014).

Therefore, research related to this topic has been shown to be timely with the purpose of highlighting issues related to the results of physical abilities and morphology, and assessments of the level of physical activity that can predict possible contents to be worked, according to the children's needs (Santos et al., 2013, Assis et al., 2015, De França et al., 2015).

In this sense, physical activity could be considered as a capacity directly related to the health of the individual, which results from his involvement in physical activities throughout his life (Sanches Neto and Betti, 2008).

Verardi et al. (2009) emphasizes that physical education should have the purpose of being developed since childhood education, in this way aiming at the possibility of physical, global, cognitive development, affective partner in search of interpersonal relationships.

Children 4 to 6 years of age, because they are connected and influenced by their parents, the ways in which they live, eat, talk, and receive stimuli of physical activity practices, fall directly into the way of living, and the characteristics that this child will carry out during their life. Parents who encourage children to practice some extra activity are leading their children to create such good habits, this understanding that it is important to practice activities, consequently in school it will have a greater resourcefulness. That in turn is not excluded from the contribution of this development.

In this way the objective of the study was to verify what physical activities are practiced by children, both inside and outside school, and whether the parents' lifestyle reflects this reality.

\section{Method}

The method used to carry out this research project is the Descriptive Research, of a correlational nature (Thomas and Nelson, 2002). However, the present study is characterized by a cross-sectional study of incidence (Bordalo, 2006). of life reflects this reality. Cross-sectional studies are recommended when estimating the frequency with which a particular health event manifests itself in a specific population, in addition to the factors associated with it (Bastos and Duquia, 2007).

The research was carried out in a private school in the State of São Paulo, in the search to reach a result if there is any influence on the physical activities of schoolchildren in children from 4 to 6 years' old who belong to traditional sedentary families. The initial population consisted of 50 
students, but the final sample, of this study, consisted of 24 children of both sexes, from 4 to 6 years of age (mean age $4.85 \pm 0.93$, coefficient of variation of $19.17 \%$, showing so the sample is homogeneous in relation to age). Of these, 13 boys evaluated and 07 girls.

The study procedures were followed by the application of an instrument elaborated by the researchers, in which it was intended to highlight the objectives of the study. Parents and / or guardians were presented with the research to be developed, followed by the delivery of the Informed Consent Form. A questionnaire with 16 questions directed to the children and 19 questions for each family member (mother, father, caregiver or guardian), capable of identifying personal information such as name, age and, among others, physical information such as weight, height and daily information and practices arising from each individual. It is justified to reduce the sample due to the exclusion criterion, which was based on students who did not present the Signed Free Consent Form.

In addition to the questionnaire, 8 classes were attended between the dates of April 1, 2017 and April 30,2017 , in which the performances and pre-dispositions of the students in the classes of physical education and observation in the participations of each student were recorded, following the questionnaire delivered. We noted in the students' own records and used the criterion to identify this pre-disposition, according to their performance and participation in all the observed classes of physical education, evaluating when they showed interest or not for them. The data was analyzed descriptively, with the frequency of the results and using graphs.

\section{RESULTS AND DISCUSSION}

Before the instruments used, it was possible to observe that of the children evaluated, $4.16 \%$ have some kind of disease or deficiency, none present food restrictions, none follow some type of diet, $100 \%$ of them practice physical school activities, but were analyzed before pre-dispositions and intensity of practices, $29.16 \%$ of the children did not show good intensity and pre-disposition, and $70.84 \%$ had good results.

We also had $54.17 \%$ of those who practiced physical activities outside of school, thus being ordered the modalities of soccer $8.34 \%$, swimming $37.5 \%$, ballet $4.16 \%$, bicycle $4.16 \%$. The frequency of practices of extracurricular physical activities ranged from 1 to 2 days in the week, with $53.84 \%$ of the children evaluated performing once a week and $46.16 \%$ of the children performing 2 times a week.

Based on the data collected through an open question in the questionnaire, activities and/ or exercises were collected that the children less and more like to practice. Among the exercises/activities that they like most stood out swimming $33.33 \%$, soccer $29.16 \%$, running $25 \%$, ballet $4.16 \%$, jumping rope $4.16 \%$ and those who enjoy all exercises $12.5 \%$. Among the exercises/ activities that least liked highlighted, soccer $4.16 \%$, running $4.16 \%$, walking $4.16 \%$ and the remaining $79.2 \%$ did not mention any activity.

Following the data of the parents can be observed, with regard to the parents, responsible or career, $2.08 \%$ reported to present chronic disease, being the most common arterial hypertension among the parents, with some deficiency none was presented, was also observed according to the data provided by the family, the parents and mothers with normal weight considered are $52.09 \%$, those overweight are $35.41 \%$ and those with obesity are $12.5 \%$.

We also found that, $14.58 \%$ do diets or dietary restrictions, $33.33 \%$ practice physical activities, being soccer $8.33 \%$, 6.65\% Pilates, $4.16 \%$ running, $4.16 \%$ hiking, 4,16\% do some kind of functional training, $16 \%$, localized gymnastics with $4.16 \%, 2.08 \%$ swimming, t2.08\% do Tai Chi Chuan and $2.08 \%$ straight training.

Of the 24 children evaluated, $29.16 \%$ had only the sedentary mother, among whom only $28.57 \%$ presented satisfactory performance during class. in the case of only the father who does not practice physical activities were $20.84 \%$, and all had a good performance in class. $29.16 \%$ of the students had both parents sedentary, and of these only $28.57 \%$, did not show a good income in class. Of the students who do not have sedentary parents who are $20.84 \%, 80 \%$ showed a good development in the accomplishment of the tasks, thus showing in our research that the family sedentary had no direct relation in the practices and pre-dispositions in the classes of physical education in school.

In a research carried out with 3 teachers of physical education of the public network of the city of Bauru with the participation of 62 children from 9 to 12 years, and through the reports of the teachers 
appeared elements that they believed that the influence and responsibility of the practices of physical activities belongs to parents and caregivers (Orti and Carrara, 2012).

On the other hand, observing genders, $37.5 \%$ of girls did not perform well during classes, and boys only had $25 \%$ who did not perform well during classes, thus showing that girls performed more negatively than boys. Guimarães (2014), who carried out a cross-sectional research in two public school, the number of participants in the research was 35 adolescents between 12 and 14 years of age, of both sexes, enrolled in the seventh grade of elementary school, which resulted in female adolescents $(61.9 \%)$ presented less involvement with physical activity were considered insufficiently active, compared to $28.6 \%$ of boys.

Observing the Figure 01 we can see that the correlation between height and weight of the children of the study is positive and grow up to a normal way, without overweight, specially only one student.

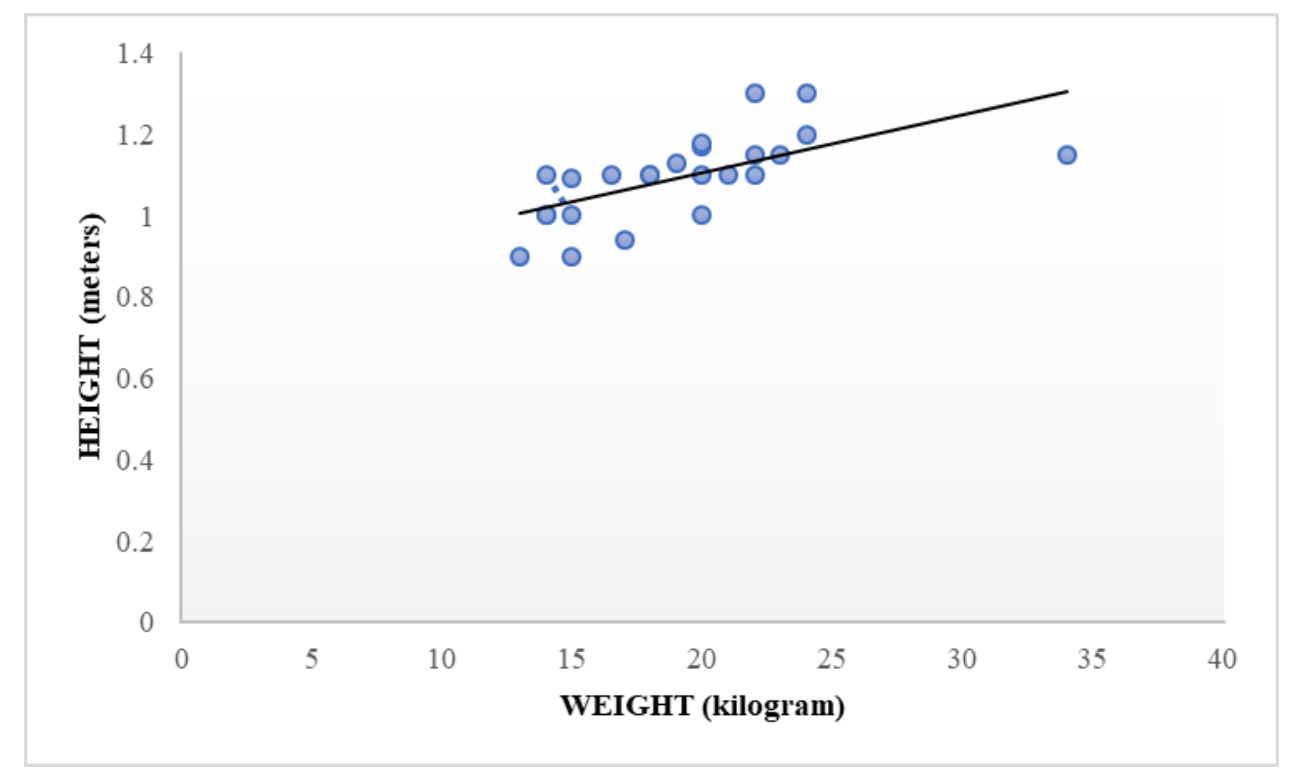

Figure1. Results of correlation between Height and Weight of children

We found that of five children whose parents are not sedentary, four did not show a good prearrangement and intensity in the practices of physical activities; among those who had sedentary parents and mothers of seven children, five had a good result in class, and only two had a negative result; with only the sedentary father, there were no changes, all the children presented a good development in the classes; of the seven mothers who are sedentary five performed well in class and only two showed no interest in them.

Observing these results, it was analyzed in our study that there is no direct influence when we refer to sedentary behavioral practices of mothers and fathers on children in their practices of physical education school activities, since even the children of sedentary and overweight parents possess predisposition in the execution of the practices and acquired a history reported by physical education teachers and interdisciplinary in the positive practices, are interested in moving, play and have insertion in the actions proposed by the teachers.

Martinez-Gomez et al. (2011), in a cross-sectional study with 110 Spanish children between 3 and 8 years of age, evaluating anthropometric measures and using an accelerometer, found that there was an inverse correlation between body adiposity and levels of physical activity.

According to Bouchard (2003) an inactive lifestyle is a risk factor for weight gain among over age. However, with the evolution of the requirements, the necessity and importance of the impact, a useful life of the parents and responsible in the life of the children, in a middle phase of the life of the same, thus being more difficult an intervention, whereas this has been consolidated and done in a pleasant way.

About this association Seabra et al (2008) explains that parents can influence the physical activity of their children directly, moving to the take their children to sports and ensure access to equipment and, in an indirect way, functioning as a model. 
This study aimed to show the levels that family sedentary lifestyle, can influence in school physical activity practices of school 4-6 years, through observation in their respective classes, and also on assessments of the responsible teacher. However, the low return of correctly completed questionnaires restricted the number of individuals surveyed which may have had interferences with the results. Thus we can consider that an active lifestyle of the parents can reflect in their sons and daughters, thinking in their future, and standing practicing exercise.

\section{REFERENCES}

[1] Minayo, MC S. et al. Fala Galera: Juventude violência e cidadania no Rio de Janeiro. Rio de Janeiro: Garamond (1999).

[2] Nascimento AM. População e família brasileira: ontem e hoje. In: Encontro Nacional De Estudos Populacionais, 15., 2006, Caxambu, MG. Anais eletrônicos... Campinas: ABEP, p.1-24 (2006).

[3] Greco PJ, Benda RN. Iniciação Esportiva Universal: da aprendizagem motora ao treinamento técnico. U.F.M.G: Belo Horizonte (1998).

[4] Aerts D, Alves GG, La Salvia MW, Abegg C. Promoção de saúde: a convergência entre as propostas da vigilância da saúde e da escola cidadã. Cad. Saúde Pública, Rio de Janeiro, 20(4):1020-1028 (2004).

[5] Nahas MV. Atividade física, saúde e qualidade de vida: conceitos e sugestões para um estilo de vida ativo. 4. ed. Londrina: Midiograf (2006).

[6] Tornquist D, Tornquist L, Reuter C, Reckziegel M, Burgos L. Physical aptitude related to the health of initial graders: A study between groups assisted and non assisted by a Physical Education professional. Revista Brasileira de Atividade Física \& Saúde,18(3):298-308 (2013).

[7] Vale SMCG. et al. Parental education and physical activity in pre-school children. Child: Health, Care and Development. 40(3): 446-452 (2014).

[8] Santos DC, Santos Filho E, Caperuto EC, De Marco A, Hirota VB. Testes de resistência anaeróbia correlacionados ao índice de massa corporal de escolares do ensino fundamental II. Revista Norte Mineira de Educação Física, 3, 17-27 (2013).

[9] Assis VG, Araujo MFF, Hirota VB. Avaliação da capacidade física força e IMC de jovens escolares. CIPPUS - Revista de Iniciação Científica da UNILASALLE, 5, 55-66 (2015).

[10] De França E, Caperuto EC, Hirota VB. Em escolares o Índice de Massa Corporal anula a diferença na capacidade física velocidade, independentemente da idade ou gênero. Revista Brasileira de Prescrição e Fisiologia do Exercício, 9, 506-514 (2015).

[11] Sanches Neto L, Betti M. Convergência e integração: uma proposta para educação física de 5 a 8 série do ensino fundamental. Revista Brasileira de Educação Física e Esporte, 22(1) (2008).

[12] Verardi CEL, Lobo APS, Fakine BGC, Barros EA, Moraes LCS, Hirota VB. A contribuição e atuação do professor de Educação Física na educação infantil. Revista Digital - Buenos Aires, 14(133) (2009).

[13] Thomas JR, Nelson JK. Research methods in physical activity. Porto Alegre: Artmed (2002).

[14] Bordalo AA. Estudo transversal e/ou longitudinal. Rev. Para. Med., Belém, 20(4), 5 (2006).

[15] Bastos JLD, Duquia RP. Um dos delineamentos mais empregados em epidemiologia: estudo transversal. Ciência Médica, Porto Alegre, 17(4), 229-232 (2007).

[16] Guimarães RBC. A influência do estilo de vida dos pais no nível de atividades físicas de filhos adolescentes. Trabalho Conclusão de Curso (2014).

[17] Bouchard C. Atividade Física e Obesidade. Barueri: Manole (2003).

[18] Martinez-Gomez D et al. Associations between moderate-to-vigorous physical activity and central body fat in 3-8-year-old children. International Journal of Pediatric Obesity, 6(2-2) 611-614 (2011).

[19] Seabra AF et al. Determinantes biológicos e sócio-culturais associados à prática de atividade física de adolescentes. Cad. Saúde Pública. Rio de Janeiro, 24(4), 721-736 (2008).

Citation: Vinicius, Barroso Hirota et al. "The Relationship between Family Lifestyle and Physical Activity of Children from 4 To 6 Years." International Journal of Sports and Physical Education (IJSPE), vol 3, no. 4, 2017, pp. 12-16. doi:http://dx.doi.org/10.20431/2454-6380.0304003.

Copyright: () 2017 Authors. This is an open-access article distributed under the terms of the Creative Commons Attribution License, which permits unrestricted use, distribution, and reproduction in any medium, provided the original author and source are credited. 